\title{
Living Arrangements of Young Adults in Europe*
}

\author{
Katrin Schwanitz, Clara H. Mulder
}

\begin{abstract}
Comparative research suggests that there are great cross-national and cross-temporal differences in living arrangements of young adults aged 18-34 in Europe. In this paper, we examine young adults' living arrangements (1) across several European countries and different national contexts, and (2) by taking into account cross-time variability. In doing so, we pay careful attention to a comprehensive conceptualisation of living arrangements (including extended and non-family living arrangements). The aim of this paper is to deepen our understanding of family structure and household arrangements in Europe by examining and mapping the cross-national and cross-temporal variety of young adults' living arrangements. For our analysis we use data from the Integrated Public Use Microdata Series International (IPUMSi) for the census rounds 1980, 1990, and 2000 for eight European countries (Austria, France, Greece, Hungary, Ireland, Portugal, Romania, and Switzerland). We employ log-linear models to ascertain the influence of individual and contextual factors on living arrangements. The analyses lend further support to a North/West - South/East divide in living arrangements and general gender differentials in extended family living. Other interesting results are the heterogeneity in the living arrangements of single mothers across geographic areas, and the upward trend of extended household living for young men and women between 1980 and 2000.
\end{abstract}

Keywords: Living arrangements · Young adults · IPUMS-International · Transition to adulthood $\cdot$ Europe

\footnotetext{
This article contains supplementary material in the form of an online Appendix: DOI 10.12765/ CPoS-2015-15en, URL: http://www.comparativepopulationstudies.de/index.php/CPoS/article/ view/158/216.
} 


\section{Introduction}

A high degree of diversity in the living arrangements of young adults has long been a characteristic European feature (Kuijsten 1996; Blossfeld et al. 2006; Fokkema/ Liefbroer 2008). Empirical research has lent particular support to strong regional patterns across groups of countries in Europe. Western and Northern Europe, for example, are generally characterised by small households (consisting of only the nuclear family members), non-familial arrangements (particularly living alone and shared arrangements), and non-residential relationships (/acovou/Skew 2011). Conversely, Southern Europe is generally characterised by large households where young adults live with their parents well into their 20 s and are likely to leave home to marry rather than to live in cohabitation or as singles. The living arrangements in Central and Eastern Europe are in many respects most similar to Southern Europe, with large households, late home-leaving, and a high frequency of multi-generational households (Ahmed/Emigh 2005; lacovou/Skew 2011). Explanations for these regional patterns in young adults' living arrangements stress, on the one hand, institutional differences in terms of the mode and scope of welfare state provisions (e.g., Esping-Andersen 1990) and, on the other hand, long-term, persistent cultural differences (e.g., Hajnal 1965; Kertzer 1991; Reher 1998) between broad geographical regions and along a North-South divide in Europe.

Numerous demographic studies have also revealed that the diversity and destandardisation of family forms, relationship and parenthood patterns in Europe has increased even further since the second half of the 20th century (Rindfuss 1991; Corijn/Klijzing 2001; Brüder/ 2004; Elzinga/Liefbroer 2007; Sobotka/Toulemon 2008; Sobotka 2008; Billari/Liefbroer 2010). These changes seem to follow a rather similar trajectory all across Europe - in fact so much so that they sparked theoretical discourses on the discontinuation of the family as an institution. Europeans are generally marrying later within the life course, and more are remaining unmarried; divorce rates have increased; non-marital cohabitation and non-marital childbearing have become more common; and "new" family forms and households (i.e., stepfamilies, living apart together arrangements) have gained visibility (Corijn/Klijzing 2001; Brüderl 2004; Billari/Liefbroer 2010).

Against this backdrop, we focus on (1) how much diversity in living arrangements is observable across European countries and (2) how the living arrangements of young adults have changed between 1980 and 2000, using data from the Integrated Public Use Microdata Series International (IPUMSi) for the census rounds 1980, 1990, and 2000 for eight European countries (Austria, France, Greece, Hungary, Ireland, Portugal, Romania, and Switzerland). Unlike previous research (e.g., Fokkema/Liefbroer 2008) - which mainly examined a small set of living arrangements and has not paid a great deal of attention to the prevalence and variations in extended living arrangements - we provide a detailed picture of young adults' living arrangements (including extended and non-family arrangements) and compare living arrangements between various groups of young adults (men and women; older and younger; people who live in different groups of countries). In doing so, we contribute to the demographic literature on the growing complexity of family forms and 
living arrangements across Europe by mapping the extent to which young adults are surrounded by their families in a variety of living arrangements in a much more detailed way than previous research did. Furthermore, we add to the debate about whether there is an asynchrony of changes in living arrangements between European countries and to what extent European diversity in young adults' living arrangements remains.

\section{Background}

This section presents a recap of what we know so far about young adults' living arrangements in Europe. First, we discuss variation in the prevalence of living arrangements over time and present theoretical frameworks describing the dynamics and bounds of variation for European societies. Second, we discuss variation in the prevalence of living arrangements across countries and highlight the way institutional arrangements shape choices of living arrangements. We then synthesise the findings of empirical research to describe more specifically how young adults live across contemporary Europe and identify knowledge gaps.

\subsection{Processes of Social Change}

Europe witnessed profound and sometimes even radical changes in marriage and family life in the second half of the $20^{\text {th }}$ century. In many countries, marriage and fertility rates have declined, divorce rates have increased, and unmarried cohabitation has become more common. In addition, the ways in which families live together have changed, as well. Young adults in most Western countries, for example, have postponed leaving the parental home, marriage, and parenthood - with various complex living arrangements characterising this trend. At the same time, living alone has increased particularly among working-age adults (e.g., Sobotkal Toulemon 2008; Billari/Liefbroer 2010). Some theorists have posited that these weakened traditional family patterns reflect underlying value changes and an overall shift towards privacy and autonomy, coined the Second Demographic Transition (SDT) (Lesthaeghe 1995). While the SDT predicts convergence of living arrangements over time, comparative research has highlighted that there are critical interdependencies between the SDT and social policies and cultural backgrounds thus suggesting persistent cross-national diversity in young adults' living arrangements (Kuijsten 1996; Sobotka 2008).

Other theorists applied a modernisation and globalisation perspective which underlines the increasing structural uncertainties in the domain of labour markets, finance, education, and family (Blossfeld et al. 2006; Mills/Blossfeld 2013). From this perspective, globalisation processes - specifically the internationalisation of markets, the intensification of competition, the spread of global networks, and the rising importance of markets (Blossfeld et al. 2006: 2) - have generated labour market transformations and labour market instability (e.g., risk of unemployment, fixed-term contracts). This in turn affected family forms and living arrangements as 
young people have tended to remain in education longer, enter the labour market at later ages, and increasingly postpone family formation. The proponents of this globalisation perspective, however, add an important specification to their model by considering country-specific and historically grown institutional settings and social structures that modify the impact of structural uncertainties. Consequently, young adults across different European countries and regions are not affected uniformly in the same way and a convergence to a new common pattern of living arrangements is empirically not observable (Blossfeld et al. 2006; Sobotka/Toulemon 2008). In this vein, some authors have particularly pointed to the role of welfare regimes shaping the impact of economic and social developments (Breen/Buchmann 2002). A specific case of social change is the transformation in the Central and Eastern European countries at the beginning of the 1990s, which happened more rapidly, more dramatically (e.g., the restructuring of welfare and policy regimes) and often in directions opposite to developments in Western Europe. This transformation brought drastic changes to family life: young adults postponed family formation and substituted non-marital cohabitation for marriage, fertility generally declined (while the proportion of extra-marital births increased), and average household size declined (while the proportion of people living alone increased) (e.g., Sobotka/Toulemon 2008).

\subsection{Conceptualising European Diversity in Living Arrangements}

Apart from changes across time, cross-national research furthermore suggests a significant impact of relatively stable institutional arrangements - like welfare regimes and policy environments - on young adults' living arrangements across Europe (e.g., Daatland/Herlofson 2003; Aassve et al. 2005; Albertini et al. 2007; Albertini/Kohli 2013; Chiuri/Del Boca 2007; Gauthier 2007; Steinbach 2012). EspingAndersen $(1990,1999)$ developed a typology of welfare regimes which has gained a pivotal role in explaining how qualitatively different welfare state provisions and employment and family policies across countries translate into different family structures and living arrangements. The main argument is that living arrangements are influenced by the organisation and provision of social care, namely by the degree to which welfare regimes are either familistic or individualistic. In countries with familistic regimes (such as Spain, Italy, and Greece), care for children or the elderly is mainly provided by the familial household and there are hardly any family policies supporting young adults or parents. Conversely, in countries with individualistic welfare regimes (such as Denmark, Sweden, Norway, Finland, Belgium and France), care for children or the elderly is provided by the state. Young adults can thus rely on a number of governmental aids and services in order to live independently from their parents. Empirical findings generally underscore the importance of welfare regimes - and their considerable and stable cross-national variation in the nature of provisions and policies - for shaping young adults' living arrangements across Europe (e.g., Aassve et al. 2002; Breen/Buchmann 2002; Aassve et al. 2005).

However, the literature has also pointed to problems in disentangling the effect of institutional arrangements and longstanding sociocultural differences (Kalmijn/ 
Saraceno 2008; Billari/Liefbroer 2010). Researchers have long pointed to systemic variation in family forms and cultures - which loosely follows a North/West-South/ East divide and remains remarkably resilient - to account for living arrangement patterns as well as patterns of family solidarity and family obligations (Hajnal 1965; Kertzer 1991; Daatland/Herlofson 2003; Hank 2007; Kalmijn/Saraceno 2008; Albertini/Kohli 2013). Reher (1998) argues that Northern and Southern European countries differ with respect to family ties. In countries with strong family ties, there are strong norms of intergenerational support, and people are more responsive to the needs of their family members (Reher 1998; Kalmijn/Saraceno 2008). In addition, prolonged coresidence of children with parents in extended family households is more common (Aassve et al. 2002). In countries with weak family ties, adult family members are more strongly committed to residential autonomy, young adults leave the parental home comparatively early, and living alone or living in nuclear households is very common.

\subsection{Young Adults' Living Arrangements in Europe}

We know from the literature in family demography that young adults' living arrangements vary greatly across Europe (e.g., Kiernan 1986; Lesthaeghe/Moors 1995; Kuijsten 1996; lacovou 2004; Hantrais 2006; Fokkema/Liefbroer 2008; Kalmijn/Saraceno 2008; Sobotka/Toulemon 2008; Hoem et al. 2009; lacovou/Skew 2010, 2011). First, young adults tend to leave the parental home comparatively early in Western and Northern Europe. The mean age at leaving home, for example, varies between 20 years in Finland and over 27 years in Italy for young women, and between under 22 years in Finland and Denmark to almost 30 years in Italy for young men (/acovou/Skew 2010). The share of young adults living with their parents is thus lower in Western and Northern Europe compared to Southern and Eastern Europe; and of those young adults who lived with their parents less than 1 percent in Denmark, the Netherlands, Ireland and Luxembourg were in a union which means living with a partner (please note that although using the terms union, relationship and couple interchangeably, we always refer to living with a partner). This proportion rises, however, to 8 percent and more in Lithuania, Latvia and Poland, and even up to 17.8 percent in Romania and 19.3 percent in Bulgaria (Choroszewicz/Wolff 2010). Second, living as a couple is generally a common living arrangement among young adults all across Europe, but again there are substantial differences: relationship formation starts early in the Northern and Western countries and rather late in the Southern European countries. For example, 48 percent of young men (aged 25) in Finland are in relationships compared to 8 percent in Italy (lacovou 2004). Furthermore, young adults in Northern and Western Europe far more often opt for unmarried cohabitation, whereas their counterparts in Southern Europe tend to live with a partner to whom they are married. In Central and Eastern Europe, relationships - not necessarily married - are formed early and young couples tend to have children early in the course of their relationship. The share of young adults living in relationships with children is thus high in Central and Eastern Europe, but levels of unmarried cohabitation vary across the region (Toulemon/Sobotka 2008; Hoem et 
al. 2009). Third, Northern and Western European households are relatively small, in part because the nuclear family is a dominant household type, but also because the proportion of single households is relatively high. Living alone is generally much more common at all ages in Northern and Western Europe than in Southern and Eastern Europe, but particularly so at younger ages. After having left the parental home, many young adults in Northern and Western Europe live alone before cohabiting or marrying and are thus more likely to live alone than their Southern and Eastern European counterparts (Fokkema/Liefbroer 2008). In Southern and Eastern Europe, however, households are larger and more often involve forms of the extended family. It is common, for example, that cohabiting or married young adults live with their parents (and possibly other relatives) (Ahmed/Emigh 2005; Toulemon/Sobotka 2008; lacovou/Skew 2011). In addition, Chambaz (2001) showed that between 25 percent and 40 percent of single parents in Southern Europe live with their parents or other relatives.

Although the literature has thus illustrated cross-national differences in living arrangements, it is important to note that many (descriptive) studies examined only a limited number of living arrangements in detail. Typically studies look at, for example, the prevalence of "young adults living with parents", "young adults living alone", and "young adults living in union", but not at the prevalence of extended or non-family living arrangements - which are grouped together with various other living arrangements (such as living as single parents or living in collective households, for example) in the residual category "other" (e.g., lacovou 2004; Fokkemal Liefbroer 2008; Sobotka/Toulemon 2008). This might be the case because there are few extended-family households in Northern and Western Europe, but also because extended and non-family living arrangements (e.g., living with non-relatives) have only lately garnered scientific attention. The challenge is to accommodate extended and non-family living arrangements in family and household demography. More recently, lacovou and Skew (2011) used EU-SILC data to study the household composition in Europe and explicitly included extended family households. This study provides important insight into the different family forms and living arrangements in Europe. Besides investigating differences in household composition it is, however, also important to investigate individuals in various living arrangements - in order to get a detailed picture of how young adults live and are surrounded by their families across Europe and how this has changed over time.

\section{Data and Methods}

We use pooled census microdata for the census rounds 1980, 1990, and 2000 from eight countries (Austria, France, Greece, Hungary, Ireland, Portugal, Romania, and Switzerland) to compare the living arrangements of young adults across Europe. (Note that we have grouped the exact census date by round, i.e., 1980, 1990 and 2000. Table 1 presents the exact census dates). We chose these eight countries on the basis of data availability, but also because comparisons among them illustrate particularly well cross-national differences in living arrangements across major 
Tab. 1: Available information and exact census dates for 8 European countries, 1980s-2000s

\begin{tabular}{llll}
\hline & $1980 s$ & $1990 s$ & $2000 s$ \\
\hline Greece & 1981 & 1991 & 2001 \\
Portugal & 1981 & 1991 & 2001 \\
Romania & 1977 & 1992 & 2002 \\
Hungary & 1980 & 1990 & 2001 \\
Ireland & 1981 & 1991 & 2002 \\
France & 1982 & 1990 & 1999 \\
Switzerland & 1980 & 1990 & 2000 \\
Austria & 1981 & 1991 & 2001 \\
\hline
\end{tabular}

Source: IPUMSi

European regions: North and Western (Austria, France, Ireland, and Switzerland), Southern (Greece and Portugal) and Central-Eastern Europe (Hungary and Romania). For the sake of simplicity, we refer to them as Western Europe, Southern and Eastern Europe, respectively. This geographic grouping has been used, for example, by lacovou (2013) in previous research on living arrangements. It moreover follows the longstanding sociocultural systems described above, for example by Hajnal (1965) and Reher (1998), as well as the regional differences of welfare regimes across Europe (Esping-Andersen 1990).

The census samples were obtained from the Integrated Public Use Microdata Series International (IPUMSi) data archive (Minnesota Population Center 2011) and consist of approximately 5 percent of the French, Hungarian, Portuguese, and Swiss population, and 10 percent of the Austrian, Greek, Irish, and Romanian population. We restrict the data analysis to young adults (i.e., men and women aged 18-34) because across all European countries, it is in this age range that the transition to adulthood unfolds, thus producing variability in living arrangements. It is important to note that there is no clear-cut definition of young adults in the demographic literature, mainly because it is difficult to identify the exact end of the transition to adulthood. Therefore, we make a rather arbitrary choice to set the upper age limit to 34 to account for increases in the time spent in education and trends towards leaving the parental home later. Furthermore, we exclude those young adults living in collective households (e.g., student dorms or military barracks) and those with missing values on the dependent variables. Missing values (i.e., refusals or don't knows) are only a minor issue, affecting at most 2 percent of the observations in our sample. The final sample size is $6,119,500$.

The IPUMSi data are a unique source of information for cross-country analyses at the European level due to its standardised methodology and harmonised questionnaires, procedure in data collection, high response rates, and large sample sizes. They include a wide variety of useful and harmonised information, including indicators of household relationships - from which we construct measures of living arrangements - and key demographic and socioeconomic factors (e.g., age and 
gender). Although the IPUMSi data are a useful and rich source to examine differentials and trends in living arrangements across Europe, they have certain limitations. First, the IPUMSi data are cross-sectional and thus we cannot assess changes in the timing and the frequency of transitions between different living arrangements. Second, apart from demographic variables the IPUMSi data do not contain other relevant information that might affect young adults' living arrangements (e.g. preferences, attitudes, and family values). Third, the data do not contain information on all European countries - especially information on Scandinavian countries is missing - and IPUMSi data thus can only be used to identify changes and patterns in a small part of Europe.

\subsection{Measurements}

We use the "Family Relationship Variables"- harmonised pointer variables that identify the presence of mother, father, spouse, and children for all household members - (Sobek/Kennedy 2009) in the IPUMSi to create nine mutually exclusive living arrangements based on the respective relationship and parental status of the young adult, and the information whether the young adults live in an extended family household: (1) with parents; (2) alone; (3) as a couple; (4) as a couple with parents and/or extended family; (5) as a couple with children; (6) as a couple with children and parents and/or extended family; (7) as single parent; (8) as a single parent with parents and/or extended family; or (9) sharing with others. An extended family household captures multiple generations (such as young adults and their parents), multiple relatives (such as siblings or any other relatives), non-relatives, or a combination of both living together. The category with parents jointly considers cases where young adults only live with their parents as well as cases in which young adults live with their parents and additional extended family members. It is possible that living alone and living with an unmarried partner are underreported in census data, because many young adults in Europe do not register address changes when leaving the parental home to live alone or with a partner or continue to report the parents' household as place of residence if they keep returning to the parental home occasionally (Sobotka/Toulemon 2008). We do not know how large such a bias is in the IPUMSi data. The category sharing with others refers to shared - but noninstitutional - accommodation of non-relatives, such as e.g., young adults sharing a flat with friends.

By using this broad categorisation, we aim to capture a wide variety of young adults' living arrangements in different stages of their life course. Because the IPUMSi data do not collect information about absent spouses or partners, our categorisation is, however, limited in regard to non-standard living arrangements (i.e., non-cohabiting couples and living apart together relationships). It is also important to note that we cannot account for multi-residence (i.e., young adults living in more 
than one household). ${ }^{1}$ In addition to living arrangements we use the following categorical variables: (1) Country (8 categories: Austria, France, Greece, Hungary, Ireland, Portugal, Romania, and Switzerland), (2) Year (3 categories: 1980, 1990, 2000), and (3) Age (4 categories: 18-19, 20-24, 25-29, 30-34). The latter variable captures the effects of age-norms and age-graded transitions in the life course. Research suggests that important life course events (i.e., leaving the parental home, getting married, or having a child) are guided by specific age norms, which in turn affect residential choices and living arrangements (see for example: Billari/Liefbroer 2007). The four age groupings used reflect those used commonly in census data. Because the scope of this article is already quite broad, we abstain from examining educational, social class or ethnicity differences in young adults' living arrangements. Studies have, however, shown that socio-economic characteristics (e.g., education and economic activity) and ethnicity shape young adults' residential decisions and living arrangements (Stone et al. 2011; Zorlu/Mulder 2010).

\subsection{Modelling Strategy and Method}

We first calculate the weighted percentage distribution for men and women by age group, year and country in order to examine prevalence and overall change in living arrangements of young adults in Europe. Subsequently, we specify log-linear models for contingency tables to adjust for the changing marginal distributions of variables (e.g., country, year, or age group) that sort young adults into different living arrangements and to describe the associations between the variables in a standardised way. We assess whether: (1) there are cross-national differences in living arrangements, (2) there are cross-temporal differences in living arrangements, and (3) the age pattern in living arrangements differs across countries.

Log-linear models are a special case of the general linear model (GLM) for Poisson - distributed data and are a powerful tool to analyse the relationships among different categorical variables - particularly for multi-way contingency tables (i.e., tables with more than $2 \times 2$ categorical variables). Log-linear models predict the expected frequencies in a contingency table, considering both main effects (that pertain to differences among the marginal distribution of a variable) and interaction effects (that pertain to associations between variables). They are different to other GLM's in that the cell counts are the response and there is thus no formal distinction in dependent and independent variables among the categorical variables in the model (Agresti 2013). A particular advantage of log-linear modelling for our purpose is that we can analyse the associations between demographic variables and changes over time net of changes in demographic composition.

1 In most censuses, some rules are applied in order to avoid double-counting of individuals (most often by restricting the observation of individuals to their main dwelling), but these rules do not allow for an accurate description of multi-residence (i.e., individuals living usually in two dwellings). 
In order to identify a best-fitting log-linear model of living arrangements, we tested, by process of backward elimination, whether any components could be removed from the saturated model (i.e., a model including all interaction and main effects). We rely on the Bayesian information criterion to assess the model fit, because $\chi^{2}$ - based test statistics may be overly sensitive to departures from the null hypothesis due to the large sample size (Raftery 1995). Our results (Table A1) indicate that a more parsimonious model than the saturated model does not fit well, since the relationship between the four variables is not homogeneous.

$\ln F_{i j k t}=\mu+\lambda_{i}^{L}+\lambda_{j}^{C}+\lambda_{k}^{Y}+\lambda_{t}^{A}+\lambda_{i j}^{L C}+\lambda_{i k}^{L Y}+\lambda_{i t}^{L A}+\lambda_{j k}^{C Y}+\lambda_{j t}^{C A}+\lambda_{k t}^{Y A A}+\lambda_{i j k}^{L C Y}+\lambda_{i j t}^{L C A}+\lambda_{i k t}^{L Y A}+\lambda_{j k t}^{C Y A}+\lambda_{i j k t}^{L C Y A}$

The log-linear model for a four-way contingency table is thus formulated below. $\mathrm{L}$ refers to the respondent's living arrangement (with $i=1, \ldots 9$ ), $\mathrm{C}$ refers to the respondent's country of residence (with $j=1, \ldots 8$ ), Y refers to the year (with $k=1, \ldots$ 3 ), and $\mathrm{A}$ refers to the age group (with $t=1, \ldots 4$ ). The statistic $\mathrm{F}_{\mathrm{ijkt}}$ represents the number of young adults in each cell of the cross-tabulation of living arrangement, country, year, and age group $(9 \times 8 \times 3 \times 4=864$ cells $)$ :

Because we apply effect coding, $\mu$ reflects the grand mean of all observations. In addition to controlling for marginal distributions of the categorical variables $\left(\lambda_{i}^{L} ; \lambda_{j}^{C} ; \lambda_{k}^{Y} ; \lambda_{t}^{A}\right)$, we also account for the four-way interaction between living arrangement, country of residence, year, and age group $\left(\lambda_{i j k \mathrm{k} t}^{L C Y A}\right)$ and all lower-order interactions. Note that we (1) estimate separate but analogous log-linear models for men and women, (2) focus on selected key parameters from the saturated model for women and men, respectively, rather than interpreting all 864 parameters, and (3) enhance substantive interpretations by looking at model parameter estimates with an effect size larger than .10 (corresponding to a 10 percent over-representation compared with a distribution determined by the marginal distributions only) and which are significant at the 5 percent level. We choose a cut-off at 10 in order to simplify the presentation of the results and not to present (negligibly) small effects (Tables A2A7 present all parameters for the two-way and three-way interactions for men and women, respectively). Note, too, that while the saturated log-linear models do not as such tell us something we do not know from the raw numbers in the descriptive table, they allow better representing higher-order interaction terms and assessing significance and effect size of the parameters.

\section{$4 \quad$ Results}

\subsection{Cross-national Differences in Living Arrangements}

The weighted percentage distributions for men and women (Tables 2 and 3, respectively) show that there are considerable regional differences: living as a couple is more common in France and Switzerland than in Southern (Greece and Portugal) and Eastern (Hungary and Romania) Europe, while Southern and Eastern Europeans 


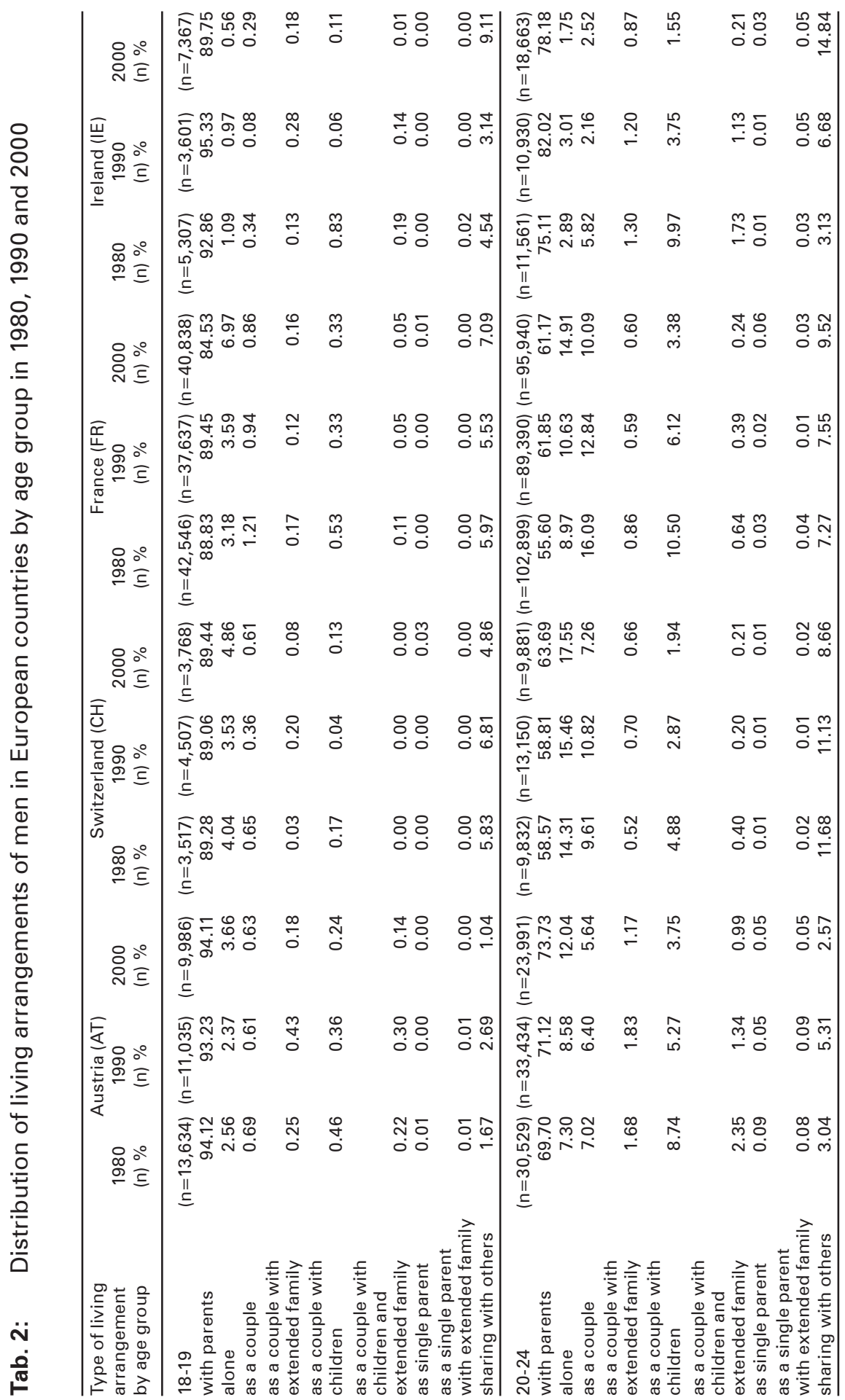




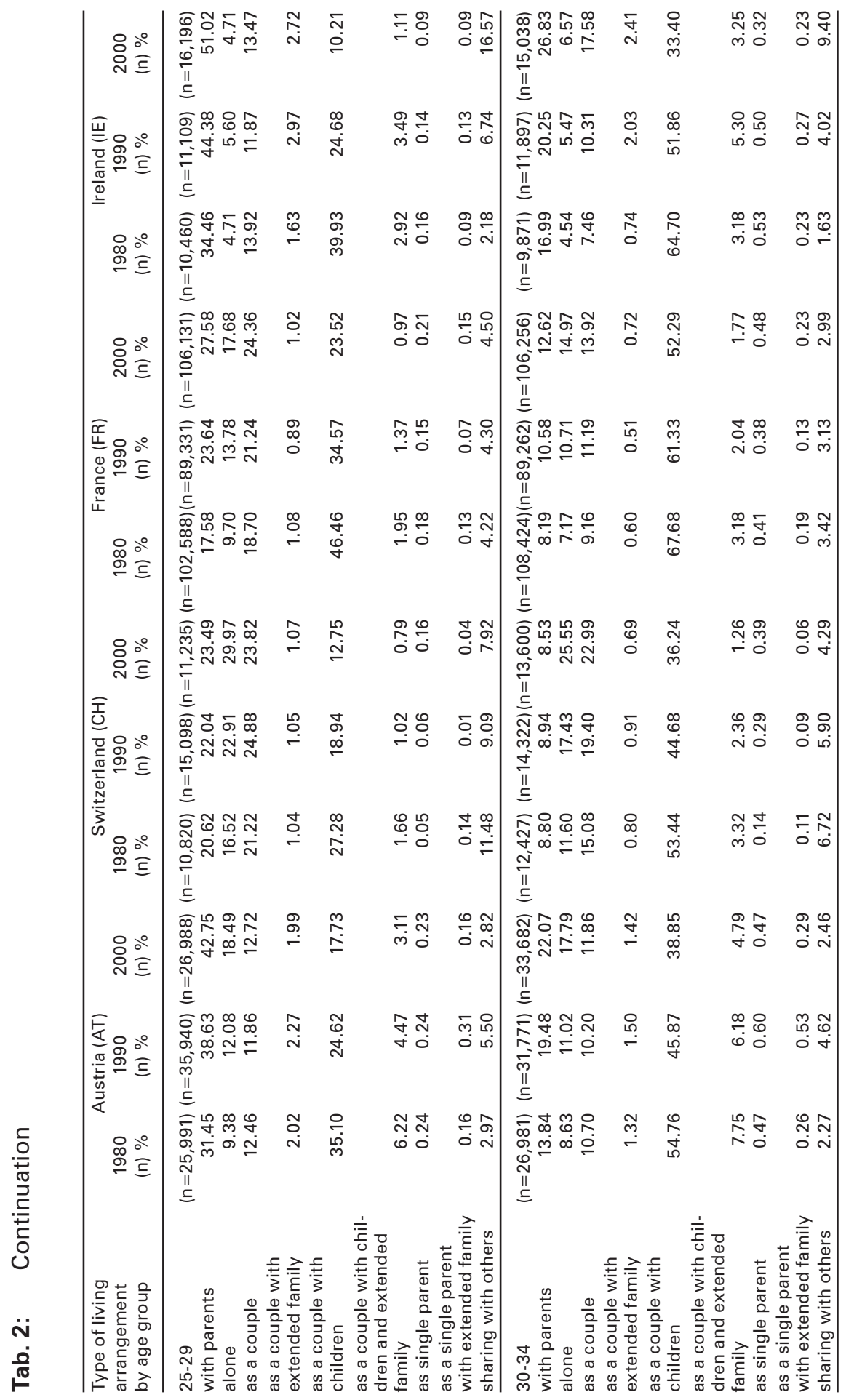




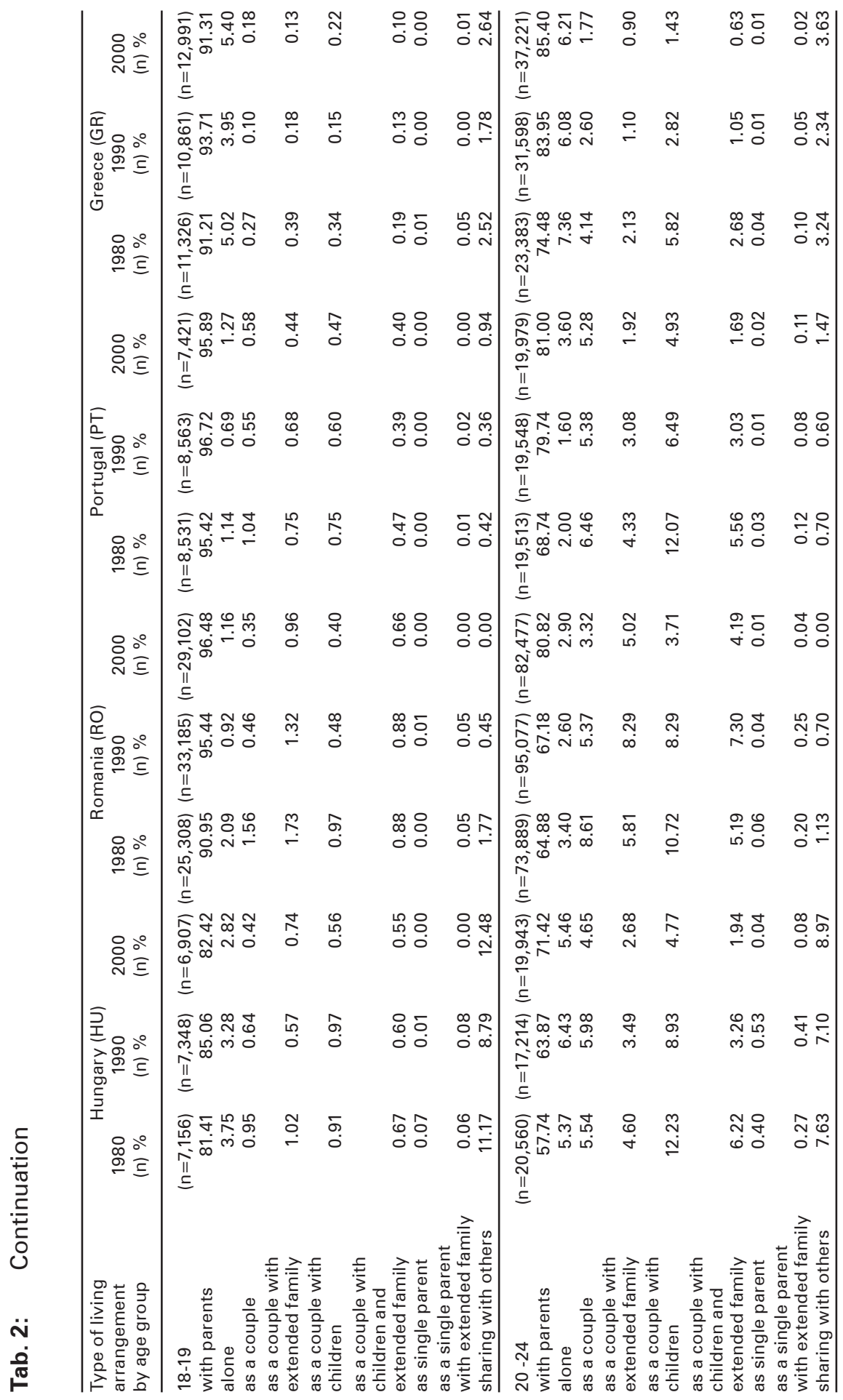




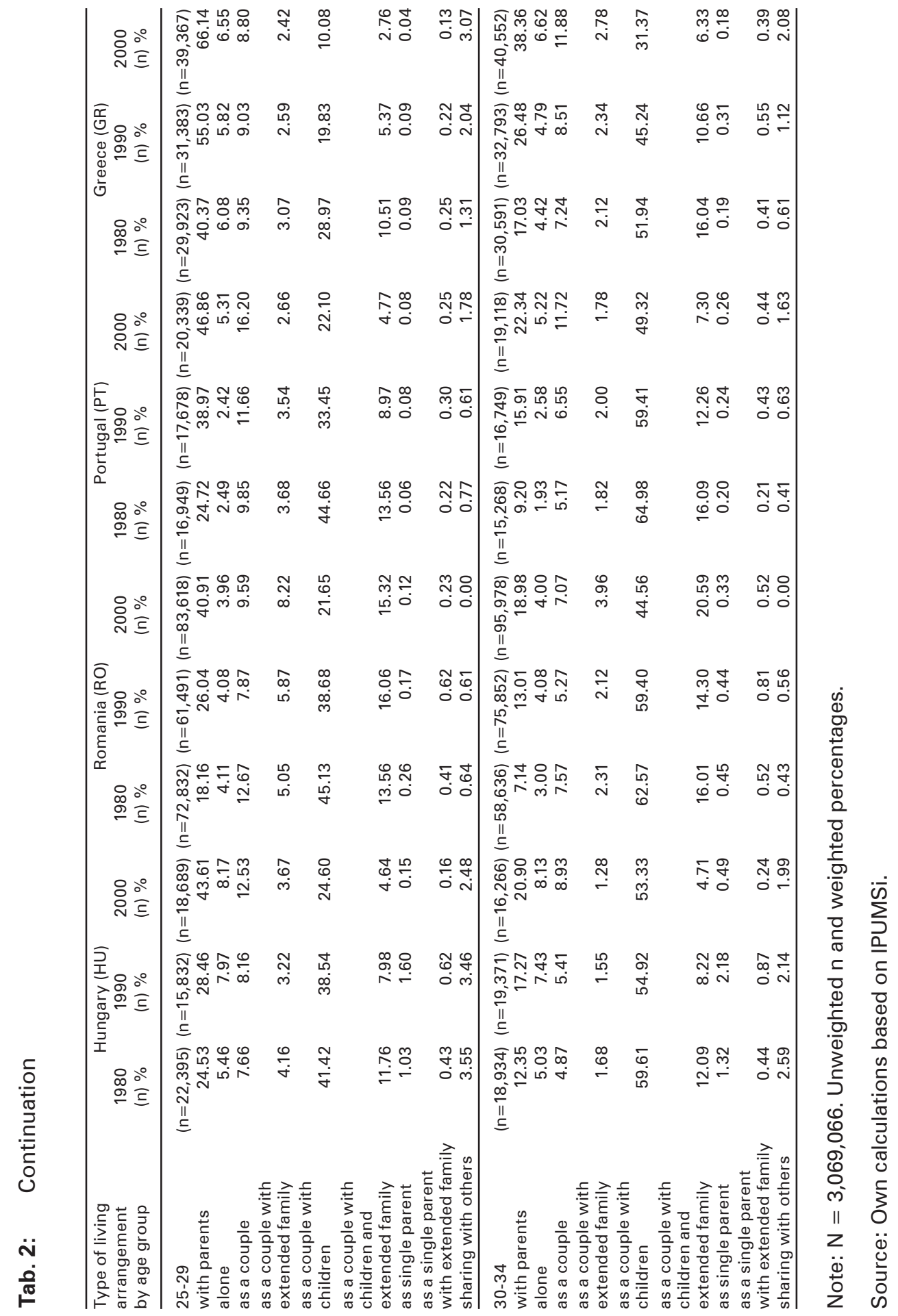




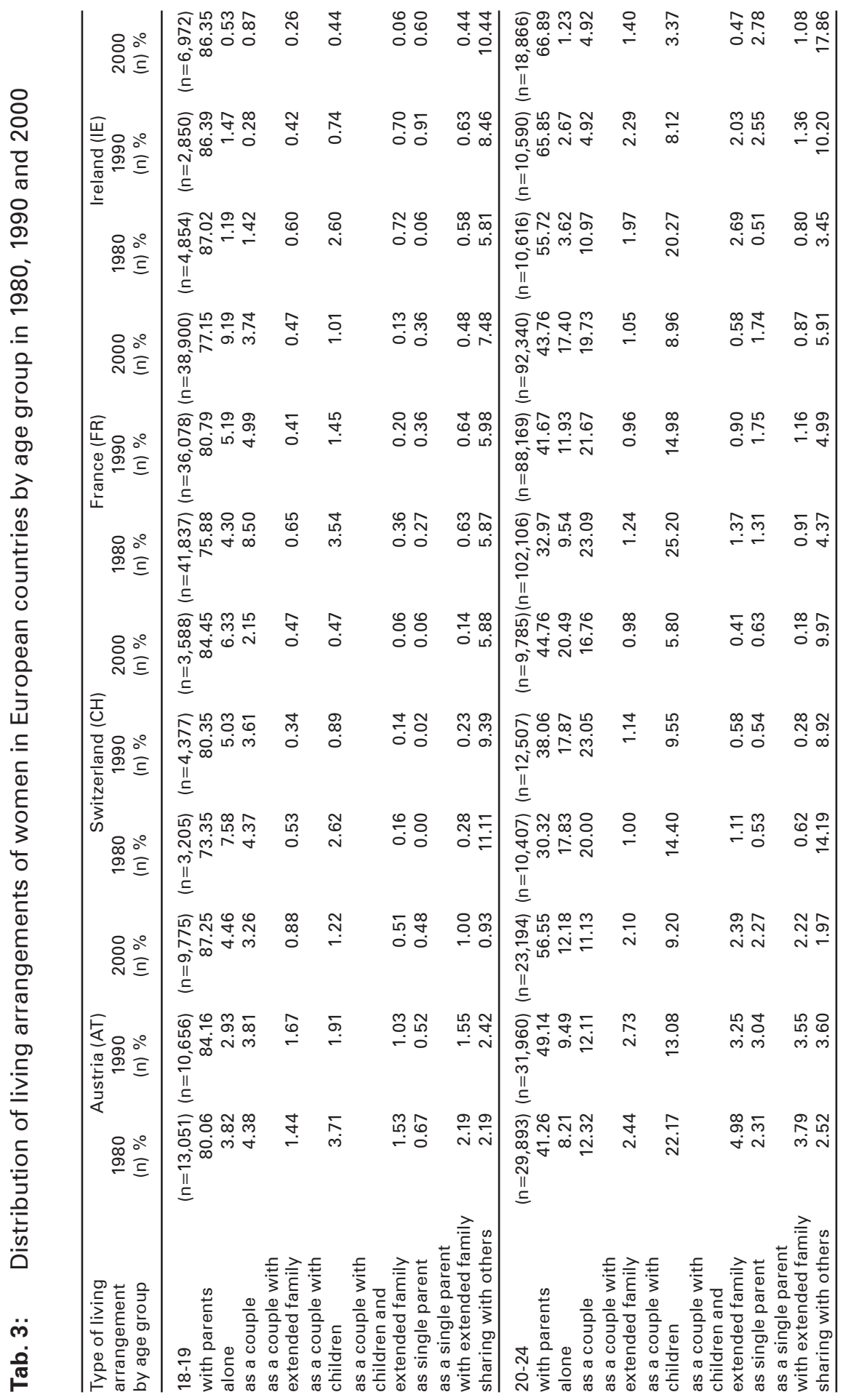




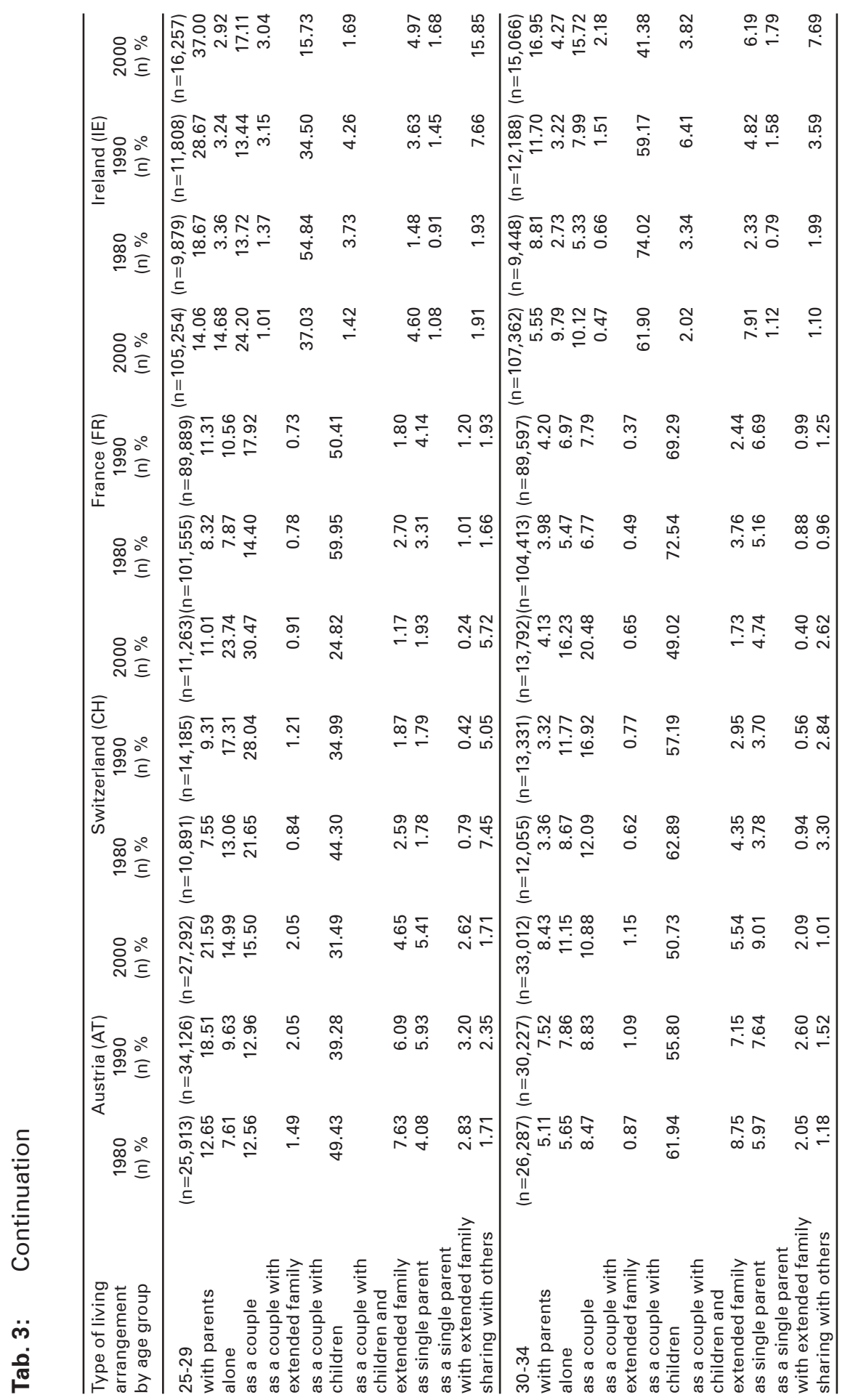




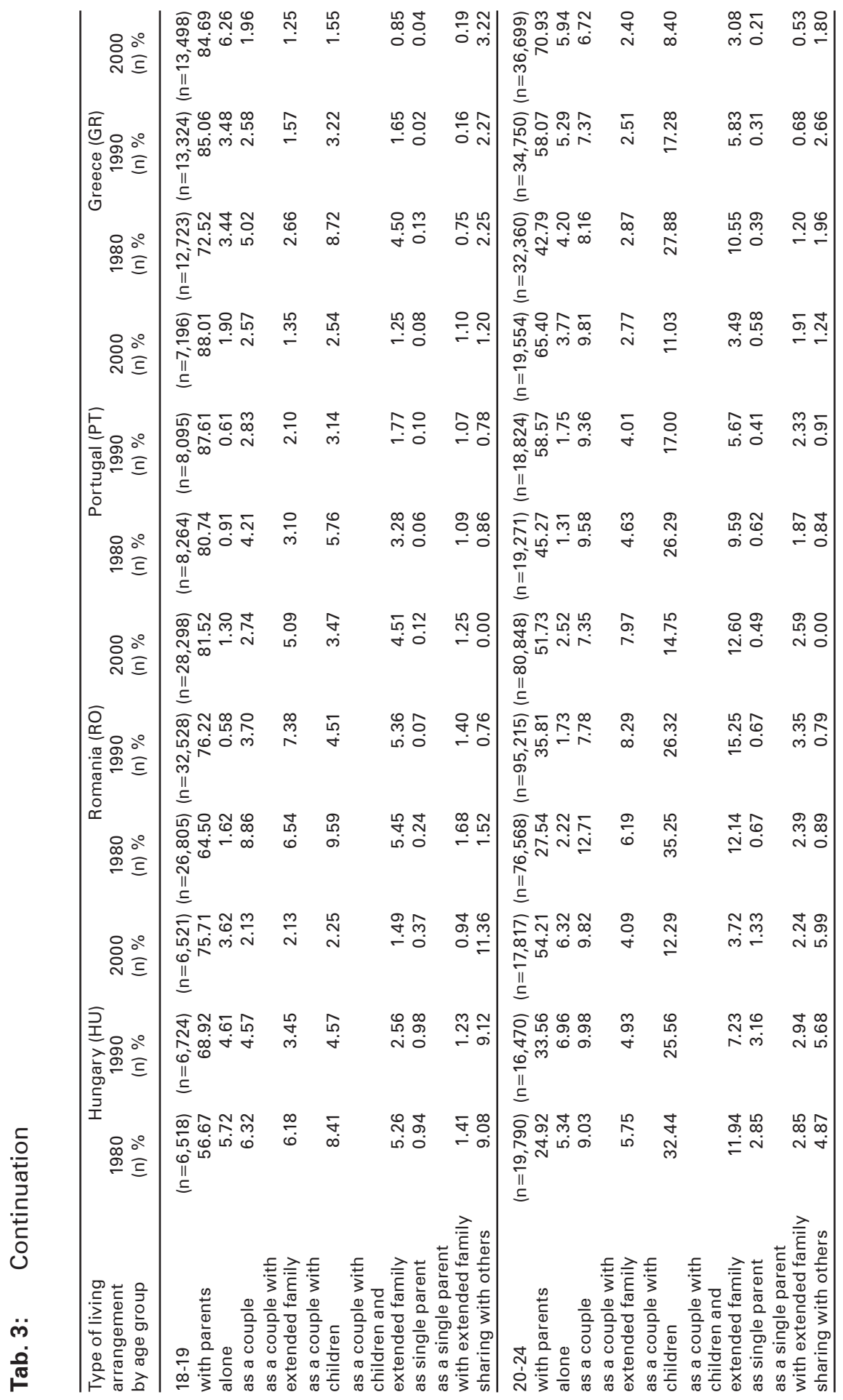




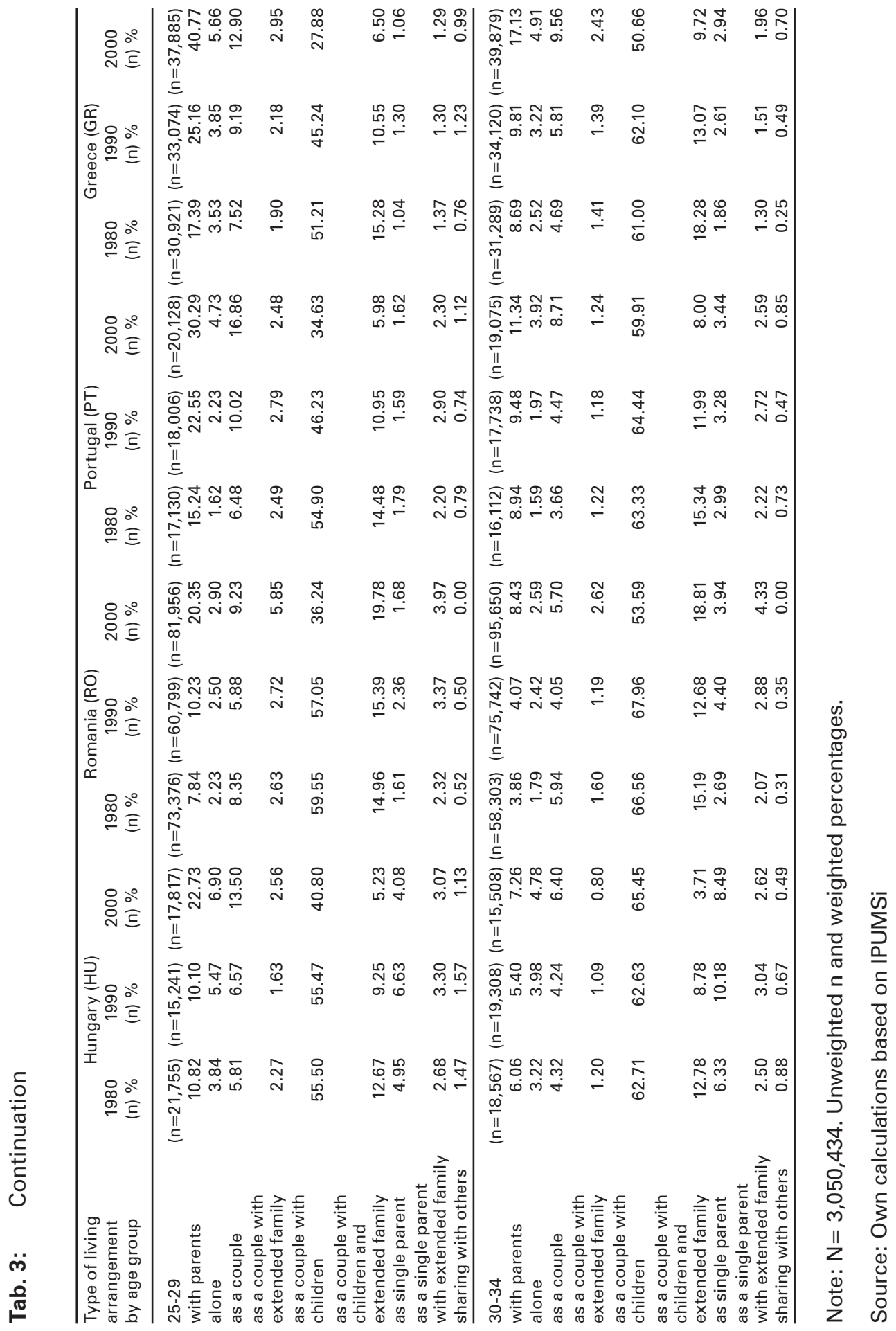


are particularly likely to live with members of the extended family - far exceeding levels in France and Switzerland. In Austria and Ireland, however, extended family living arrangements (i.e., couples with children and parents and/or extended family) are quite common, particularly for young adults in the age group of 30-34 years which mirror their Southern and Eastern European counterparts. Similarly, living with parents is considerably more common in Southern and Eastern Europe in the older age groups (i.e., 25-29 years old and 30-34 years old, respectively) than in Western Europe (Austria, France, Ireland, and Switzerland). We furthermore find that across age groups living alone and sharing with others is generally $\mathrm{m}$ Distribution of living arrangements of WOMEN in European countries by age group in 1980, 1990 and 2000ore prevalent in Western European countries and Hungary than in Southern and Eastern Europe. Living as a couple with children is the most common living arrangement for both men and women and the differences between the countries are relatively small.

The parameter estimates for the two-way interaction between living arrangement and country $\left(\lambda_{i j}^{L C}\right)$ from our log-linear model are shown in Figures 1 and 2 (for men and women, respectively); the effect sizes are drawn as country abbreviations along the $x$-axis for each of the nine living arrangements. Positive parameters display overrepresentation and negative parameters underrepresentation with regard to the two-way interaction. For example, we see in Figure 1 that the country abbreviation $\mathrm{CH}$ (= Switzerland) has a positive parameter (i.e., is situated to the right of 0 ) for the living arrangement alone. This means that living alone is overrepresented among young men in Switzerland. The opposite holds if a country abbreviation has a negative parameter. More substantively, we see that there are considerable differences in living arrangements across countries: Southern and Eastern Europeans are particularly likely to live with their parents and/or extended family. A case in point is living as a single parent with parents and/or extended family, which is more common in Southern and Eastern Europe. As a Western European country Ireland interestingly shows that young adults are more likely to be in the category living with parents, which means that they are in this respect closer to young adults in Southern and Eastern Europe. If we now look at non-family living arrangements (i.e., sharing with others and living alone), we see that these living arrangements are generally more common in Western Europe. For example, young adults are more likely to live alone in Austria, France, and Switzerland - but not in Ireland. And finally, living as a couple is more common in France and Switzerland - but not in Austria and Ireland or Southern and Eastern Europe.

\subsection{Cross- temporal Differences in Living Arrangements}

Again, we turn first to Tables 1 and 2, and see that there is an upward trend of living with parents between 1980 and 2000, but the increase for the age groups 20-24, 25-29, and 30-34 was much stronger in the Southern and Eastern European countries than in Western Europe. At the same time, living alone increases in Austria, Switzerland, and France across all age groups, but only slightly in the Southern and Eastern European countries and Ireland. Across all countries there is a decrease in 
Fig. 1: Cross-national and cross-temporal differences in young men's living arrangements. Lambda parameters for the two-way (LC) and three-way interaction (LCY)

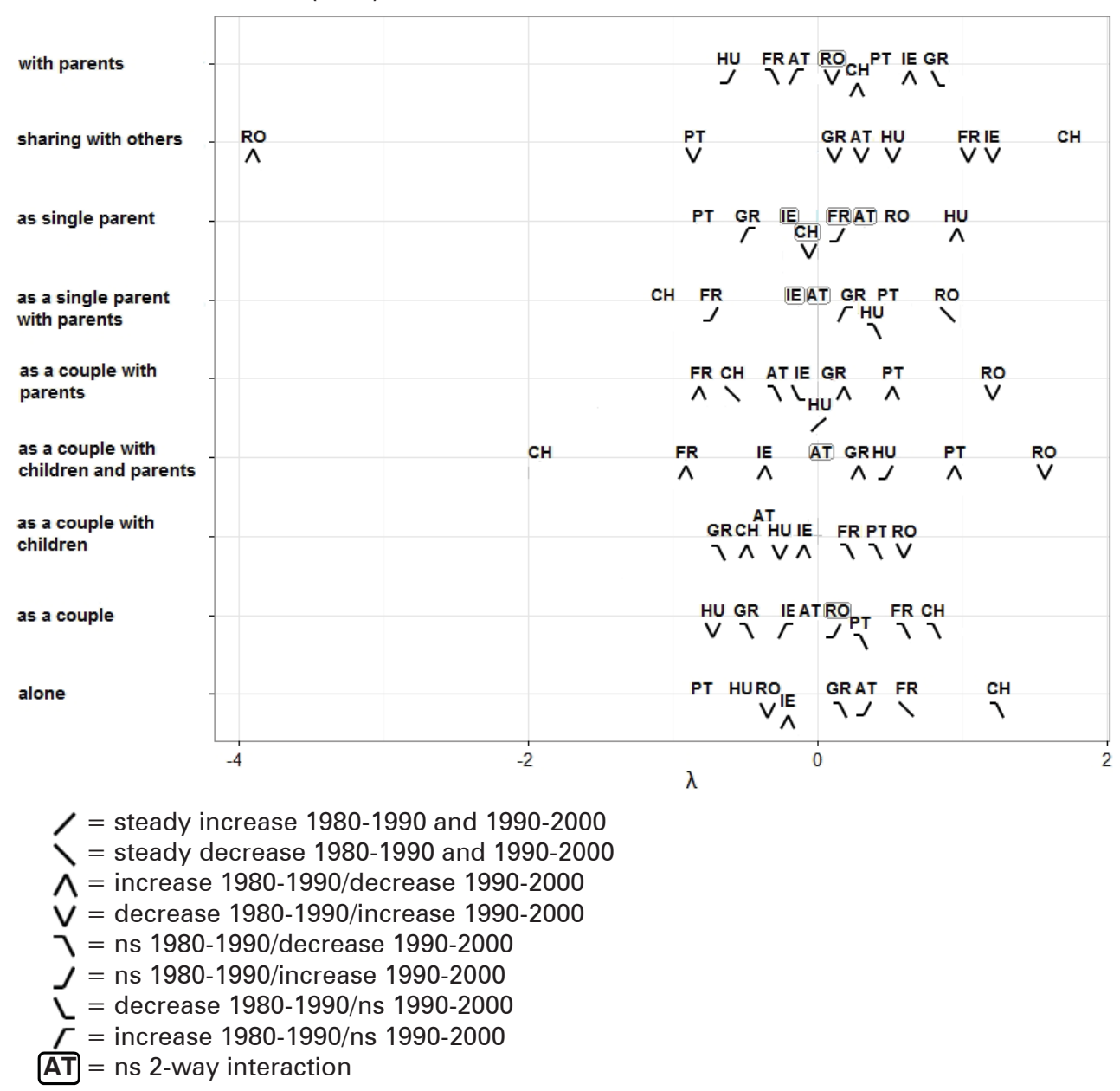

Note: $\mathrm{AT}=$ Austria; $\mathrm{CH}=$ Switzerland; $\mathrm{IE}=$ Ireland $\mathrm{FR}=$ France; $\mathrm{GR}=$ Greece; $\mathrm{HU}=$ Hungary; $\mathrm{PT}=$ Portugal; $\mathrm{RO}=$ Romania .

Source: Own calculations based on IPUMSi

the percentages of young adults living as a couple with children. While the change over time for women generally mirrors that of their male counterparts, sex differences have not diminished over time. The importance of the cross-national comparison becomes salient when we examine changes in living arrangements over time in the European countries. To obtain more insight into the changes over time between 1980 and 2000, Figures 1 and 2 additionally present two parameter estimates for the three-way interaction between living arrangement, country and year $\left(\lambda_{i j k}^{L C Y}\right)$ from our log-linear model. Below each two-way interaction, we display over- 
Fig. 2: Cross-national and cross-temporal differences in young women's living arrangements. Lambda parameters for the two-way (LC) and three-way interaction (LCY)

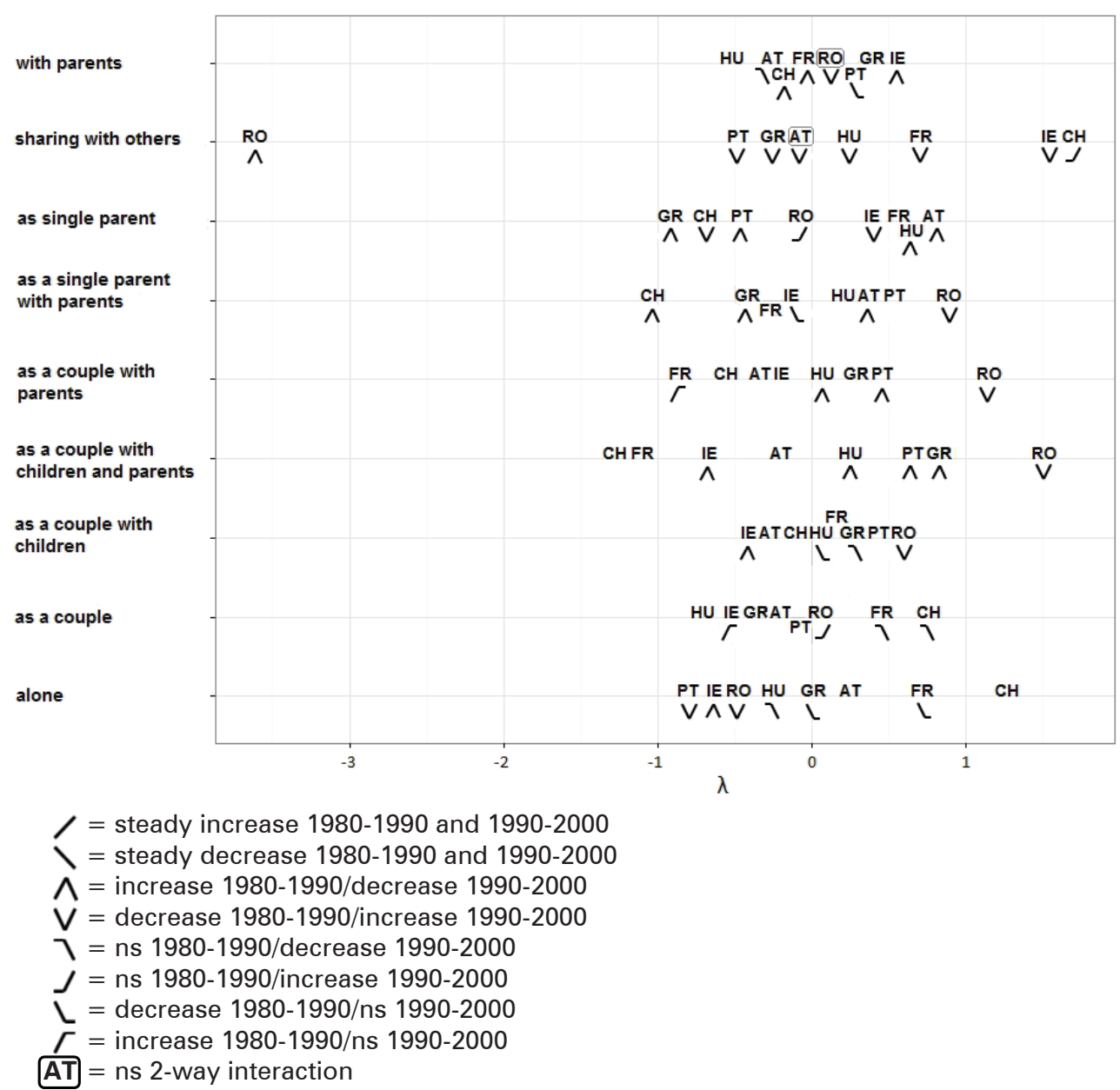

Note: $\mathrm{AT}=$ Austria; $\mathrm{CH}=$ Switzerland; IE = Ireland; FR = France; GR = Greece; $\mathrm{HU}=$ Hungary; $\mathrm{PT}=$ Portugal; $\mathrm{RO}=$ Romania .

Source: Own calculations based on IPUMSi

and underrepresentation for the year 1980 and 2000, respectively by a line pointing up or down. For example, in Figure 1 we see a line pointing down \below the country abbreviation FR (=France) for the living arrangement alone. This means that living alone is underrepresented in both 1980 and 2000 (i.e., steadily decreased between the two time points) among young men in France. More substantively, we see that for both men and women across almost all countries - Romania being the exception - there was an upward trend in non-family living arrangements between 1990 and 2000. For example, it was more likely that young adults are sharing with 
others in 2000 compared to other years. Similarly, we see that between 1990 and 2000 there was a general downward trend across almost all countries in living as a couple with parents and/or extended family, and as a couple with children and parents and/or extended family. In Hungary and Romania, however, opposite changes occurred in the same period and extended family living arrangements did not become less common over time here. Finally, we see that young men and women have become less likely to be living as a couple in France and Switzerland in 2000 compared to other years.

\subsection{Age Differences in Living Arrangements by Country}

Figures 3 and 4 present (for men and women, respectively) the parameter estimates for the three-way interaction between living arrangement, country and age group $\left(\lambda_{i j t}^{L C A}\right)$; we display over- and underrepresentation for each age group (by country and living arrangement) with big and small circles. For example, we see in Figure 3 for the living arrangement alone in HU (= Hungary) two small circles for the age groups of 18-19 and 20-24 years and one big circle for the age group 30-34 years. This means that living alone is underrepresented in the two younger age groups but overrepresented in the oldest age group among young men in Hungary. The order of circles along the $x$-axis points to the order of the magnitude of the effects. Substantively, the results indicate country patterns for different age groups: it is generally more likely in Southern and Eastern European countries that young adults in the age groups of 18-19 and 20-24 years are either living as a couple, as a couple with children, as a couple with parents and/or extended family, or as a couple with children and parents and/or extended family, whereas young adults in Western European countries are underrepresented among these younger age groups and living arrangements. This pattern is quite similar for men and women, but we note that the age pattern for young men in Austria and Greece mimics that of Southern and Eastern Europe, and Western Europe, respectively. The results furthermore indicate that both young men and women in the age groups of 25-29 and 30-34 years are more likely to be in the category living with parents in Southern and Eastern Europe. For young adults sharing with others, however, the age pattern is less clear and we do not see a clear North/West - South/East divide. Similarly, the age pattern of young adults living alone in Greece is similar to those in Western Europe, and of young adults living alone in Ireland similar to Southern and Eastern Europe. Living as a single parent and living as a single parent with parents and/or extended family is least likely for young women in the age groups of 25-29 and 30-34 years in Western Europe, while it is more likely in the same age groups for their Southern and Eastern European counterparts.

\subsection{Sex Differences in Living Arrangements}

If we compare the descriptive results from Tables 1 and 2 with respect to sex differences, we see that living with parents is much more common for men than for women across all countries and age groups. In addition, men are more often sharing 
with others or living alone. The results also show that living as a single parent and living as single parent with parents and/or extended family are very much female living arrangements. Across all countries a maximum of only 2 percent of the men live in a single parent arrangement. Women live more frequently as single parents (and thus without parents or extended family) in Austria, France, Switzerland, but also in Ireland. By comparison, there are no large differences between living as single parent and living as single parent with parents and/or extended family in Romania, Portugal, and Greece. The changes over time are generally similar for men and women, but there are slight differences with respect to the various living arrangements of young couples. Here, the changes for women were less strong but did follow a cross-national pattern. Figures 3 and 4 illustrate furthermore that there are divergent trends of living as a single parent with parents and/or extended family between men and women. We should be cautious, however, to draw conclusions from this, because the proportion of men living in such a living arrangement is too small. For women, we see a regional pattern that is in line with the other extended living arrangements: in Western and Southern Europe single parents living with parents and/or extended family have become less common over time in all countries but Ireland, while it has become more common in Romania.

\section{$5 \quad$ Conclusions and Discussion}

This paper focuses on variation in young adults' living arrangements across eight European countries and different national contexts, as well as taking into account cross-time variability. Drawing on IPUMSi data for the census rounds 1980, 1990, and 2000 for eight European countries (Austria, France, Greece, Hungary, Ireland, Portugal, Romania, and Switzerland), we examined associations between young adults' living arrangements, country, year, and age group, controlling for the changing marginal distributions of these characteristics, for men and women. Because we capture a wide variety of young adults' living arrangements and explicitly include extended family living arrangements and non-family living arrangements, our findings are a unique contribution to the literature on young adults' living arrangements in Europe. Furthermore, we add to the debate about changes in living arrangements between European countries and European diversity in living arrangements. Methodologically, our analysis builds on saturated models, which do not reduce the complexity of estimating cell counts in the contingency table, but nevertheless provide a straightforward measure to assess cross-national and cross-temporal differences in young adults' living arrangements differences. Because we are primarily concerned with describing regional differences and trends in young adults' living arrangements, we concentrate on selected key parameters.

Our first question addressed how much diversity in living arrangements is observable across European countries. We found that there are country differences for almost all nine living arrangements of young adults. The exception is living as a couple with children, which is a dominant living arrangement across all countries particularly among older age groups (i.e., 25-29 years and 30-34 years). But diversity is es- 
390 - Katrin Schwanitz, Clara H. Mulder

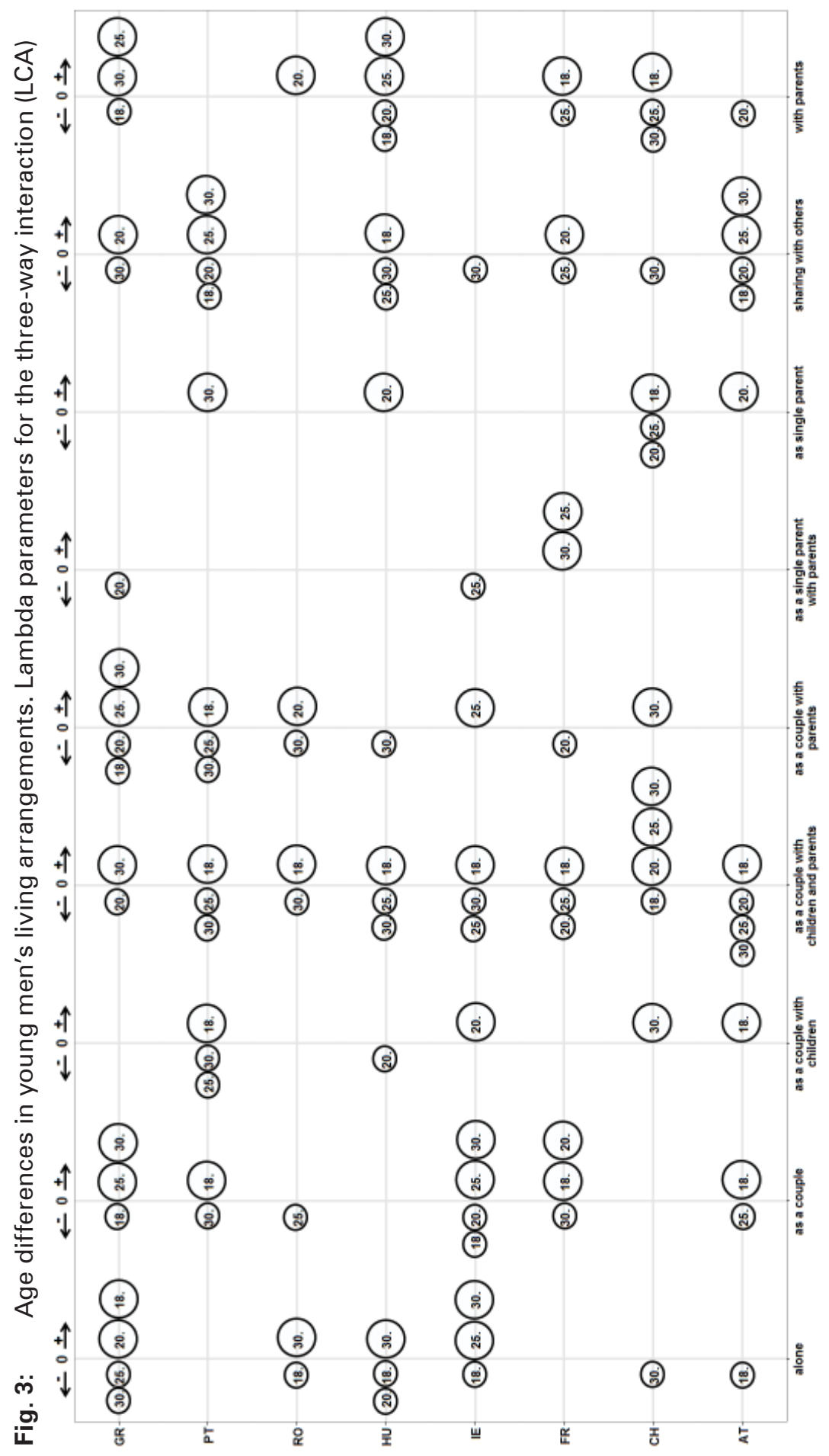




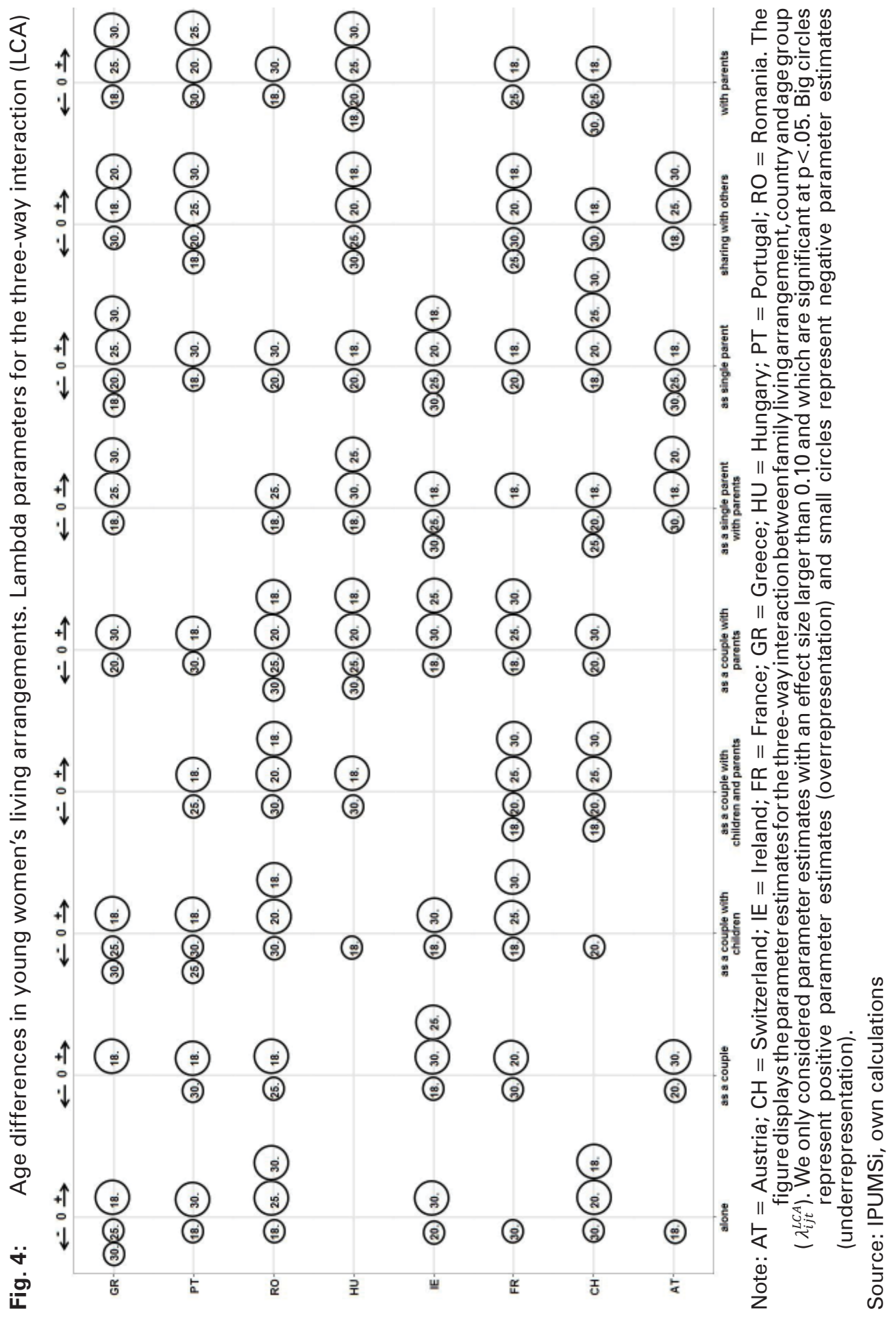


pecially pronounced if we look at extended and non-family living arrangements. Net of demographic controls, living alone or sharing with others is significantly more common in Western European countries, whereas living with parents, living as a couple with parents and/or extended family, and living as a couple with children and parents and/or extended family is significantly more common in Southern and Eastern Europe. This pattern is generally compatible with longstanding, systemic variation in family forms and cultures that follows a North/West - South/East gradient (Hajnal 1965; Reher 1998). Nonetheless, we note that Ireland and Austria are much more similar to Southern and Eastern Europe with respect to (some) extended family living arrangements: living with parents and living with parents and/or extended family, respectively. It could be, for example, that a significant proportion of Southern and Eastern European young adults - namely those at younger ages, without a partner and those being single parents - are living with parents and/or extended family to rely on intergenerational assistance in shared living arrangements, given the smaller provision of institutional support in these countries, as prior research suggests (Chambaz 2001; Sobotka/Toulemon 2008; Albertini/Kohli 2013).

Our second question asked how the living arrangements have changed between 1980 and 2000. We found that the changes over time also differed across countries: extended family living arrangements (i.e., as a couple with parents and/or extended family, or as a couple with children and parents and/or extended family) have become less common between 1980 and 2000 in Western and Southern Europe, but not in Hungary or Romania. Furthermore, there has been an upward trend - especially in Southern and Eastern Europe - of both young men and women living with parents between 1980 and 2000. This period also marked an increase in non-family living arrangements in Austria, Switzerland, and France, but not in Ireland and Southern and Eastern Europe. But we also found similar changes across European countries - particularly a decline in young adults living as a couple with children over time (although most young adults aged 25 years or older still live with a partner and children). These results are generally in line with prior research (e.g., Fokkema/ Liefbroer 2008; Sobotka/Toulemon 2008; Billari/Liefbroer 2010) and might suggest that longer time spent in education, later labour-market entry, and postponement of relationship and family formation translates into young adults staying longer with their parents in Southern and Eastern Europe and Ireland, while young adults in Western and Northern Europe leave earlier and live at least for some time alone or share a flat with others before married or unmarried cohabitation. It is important to note that extended living arrangements are quite robust in (parts) of Eastern Europe. This might suggest that a mix of economic constraints, housing and labour markets as well as the transition to market economy in Eastern Europe have affected living arrangements of young adults (/acovou 2004; Sobotka/Toulemon 2008).

We furthermore investigated differences in young adults' family living arrangements by socio-demographic groups. We found that men are more likely to be living with their parents than women across all countries, but while these sex differences are generally similar across age groups in Southern and Western Europe, living with parents is most apparent among men from younger age groups in Western Europe. Both men and women in Eastern Europe - rather than just living as a couple - seem 
to be more likely to live as a couple in an extended family living arrangement (e.g., as a couple with parents and/or extended family, or as a couple with children and parents and/or extended family). The largest differences between men and women, generally, pertain to living as a single parent and living as a single parent with parents and/or extended family. It is well documented in previous research that the age-structuring of life course events is different for young men and women (e.g., Fokkema/Liefbroer 2008; Sobotka/Toulemon 2008; Billari/Liefbroer 2010; lacovou/ Skew 2011). Young women, in general, make transitions (e.g., forming relationships, having a first child) earlier than men. Although early relationship and family formation may also be related to biological limits of fertility, research has highlighted the importance of age norms that capture concepts about the timing, sequencing and duration of life course events and which affect young adults' demographic and residential choices (Billari/Liefbroer 2007). In this light, our results are not surprising, but it is nonetheless interesting to note that single young mothers in Eastern Europe particularly tend to live with parents and/or extended family and not alone. With respect to differences between age groups the results are consistent with previous findings and have been noted before (e.g., Kuijsten 1996; Fokkema/Liefbroer 2008; Sobotka/Toulemon 2008): in Southern and Eastern Europe it is much more common for young adults at younger ages (18-19 and 20-34) to live with a partner and children and at older ages (25-29 and 30-34) to live with their parents. Because our data are cross-sectional we cannot separate whether these differences are due to cohort or age effects.

In general, our results on young adults' family living arrangements match prior research findings regarding regional differences and the North/West - South/East divide (e.g., Kalmijn/Saraceno 2008; Billari/Liefbroer 2010). But our results have also shown that, despite regional patterns in family living arrangements, countries remain strikingly different - cases in point in our analysis are Ireland and Austria. It is a common puzzle of comparative research that studies do not always establish homogeneity in the outcome under consideration between all countries in one regional or welfare type classification. We do not claim that the exceptions we have found justify overturning these classifications - more observations like this would be needed - but that an understanding of the variation in family living arrangements across Europe also warrants to be cautious about country-specific circumstances (including the cultural, religious, socio-economic and policy context). Our findings moreover highlight the decrease in extended family living arrangements between 1980 and 2000 in Western and Northern Europe, which is largely absent in Eastern Europe, and update our understanding of family living arrangements in Europe. For future research, we suggest to expand the analysis to more European countries in order to arrive at a more complete picture about cross-national variation in family living arrangements and its determining factors. The choice of data sources is crucial in this respect. Although the IPUMSi data are of particular value due to their sample sizes and reliable measures across countries, they do not cover the whole of Europe. It would be particularly interesting to include the Scandinavian and Baltic countries into further analysis. 


\section{Acknowledgements}

Katrin Schwanitz's work was conducted under the remit of the iPOPs laboratory of excellence, supported by heSam Université, under the reference ANR-10-Labx -0089. The authors would like to thank the two anonymous reviewer for their valuable comments and suggestions, and also wish to acknowledge the statistical offices that provided the underlying data making this research possible: Austria, National Bureau of Statistics; France, National Institute of Statistics and Economic Studies; Greece, National Statistical Office; Hungary, Central Statistical Office; Ireland, Central Statistics Office; Portugal, National Institute of Statistics; Romania, National Institute of Statistics; Switzerland, Federal Statistical Office.

\section{References}

Aassve, Arnstein et al. 2002: Leaving home: a comparative analysis of ECHP data. In: Journal of European Social Policy 12,4: 259-275 [http://esp.sagepub.com/content/12/4/259].

Aassve, Arnstein; Mazzuco, Stefano; Mencarini, Letitia 2005: Childbearing and wellbeing: a comparative analysis of European welfare regimes. In: Journal of European Social Policy 15,4: 283-299 [doi: 10.1177/0958928705057262].

Agresti, Alan 2013: Categorical Data Analysis. New York: John Wiley \& Sons.

Ahmed, Patricia; Emigh, Rebecca J. 2005: Household composition in post-socialist Eastern Europe. In: International Journal of Sociology and Social Policy 25,3: 9-41 [doi: 10.1108/01443330510791117].

Albertini, Marco; Kohli, Martin 2013: The generational contract in the family: An analysis of transfer regimes in Europe. In: European Sociological Review 29,4: 828-840 [doi: 10.1093/esr/jcs061].

Albertini, Marco; Kohli, Martin; Vogel, Claudia 2007: Intergenerational transfers of time and money in European families: common patterns - different regimes? In: Journal of European Social Policy 17,4: 319-334 [doi: 10.1177/0958928707081068].

Billari, Francesco C.; Liefbroer, Aart C. 2007: Should I stay or should I go? The impact of age norms on leaving home. In: Demography 44,1: 181-198 [doi: 10.1353/ dem.2007.0000].

Billari, Francesco C.; Liefbroer, Aart C. 2010: Towards a new pattern of transition to adulthood? In: Advances in Life Course Research 15,2-3: 59-75 [doi: 10.1016/j. alcr.2010.10.003].

Blossfeld, Hans-Peter; Klijzing, Erik; Mills, Melinda; Kurz, Karin 2006: Globalization, Uncertainty and Youth in Society: The Losers in a Globalizing World. London/New York: Routledge.

Breen, Richard; Buchmann, Marlis 2002: Institutional variation and the position of young people: A comparative perspective. In: The ANNALS of the American Academy of Political and Social Science 580,1: 288-305 [doi: 10.1177/000271620258000112].

Brüderl, Josef 2004: Die Pluralisierung partnerschaftlicher Lebensformen in Westdeutschland und Europa. In: Aus Politik und Zeitgeschichte 19: 3-10 [http://www.bpb. de/apuz/28344/die-pluralisierung-partnerschaftlicher-lebensformen-in-westdeutschland-und-europa? $\mathrm{p}=$ all] . 
Chambaz, Christine 2001: Lone-parent families in Europe: A variety of economic and social circumstances. In: Social Policy \& Administration 35,6: 658-671 [doi: 10.1111/14679515.00259].

Chiuri, Maria C.; Del Boca, Daniela 2007: Living arrangements in Europe: exploring gender differences and institutional characteristics. In: ChilD Working Paper 2007-24 [http://esp.sagepub.com/content/15/4/283].

Choroszewicz, Marta; Wolff, Pascal 2010: 51 million young EU adults lived with their parent(s) in 2008. In: Eurostat Statistics in Focus 2010-50.

Corijn, Martine; Klijzing, Erik 2001: Transitions to adulthood in Europe. Dordrecht: Kluwer Academic Publishers.

Daatland, Svein O.; Herlofson, Katharina 2003: "Lost solidarity" or "changed solidarity": a comparative European view of normative family solidarity. In: Ageing \& Society 23,5: 537-560 [doi: 10.1017/S0144686X03001272].

Elzinga, Cees H.; Liefbroer, Aart C. 2007: De-standardization of family-life trajectories of young adults: A cross-national comparison using sequence analysis. In: European Journal of Population 23,3-4: 225-250 [doi: 10.1007/s10680-007-9133-7].

Esping-Andersen, Gosta 1990: The Three Worlds of Welfare Capitalism. Cambridge: Polity Press.

Esping-Andersen, Gosta 1999: Social Foundations of Postindustrial Economies. New York: Oxford University Press.

Fokkema, Tineke; Liefbroer, Aart C. 2008: Trends in living arrangements in Europe: Convergence or divergence? In: Demographic Research 19: 1351-1418 [doi: 10.4054/DemRes.2008.19.36].

Gauthier, Anne H. 2007: Becoming a young adult: An international perspective on the transitions to adulthood. In: European Journal of Population 23,3-4: 217-223 [doi: 10.1007/s10680-007-9130-x].

Hajnal, John 1965: European marriage patterns in perspective. In: Glass, David V.; Eversley, David E. C. (Eds.): Population in history. Essays in historical demography. London: Arnold: 101-143.

Hank, Karsten 2007: Proximity and contacts between older parents and their children: A European comparison. In: Journal of Marriage and Family 69,1: 157-173 [doi: 10.1111/j.1741-3737.2006.00351.x].

Hantrais, Linda 2006: Living as a family in Europe. In: Hantrais, Linda; Philipov, Dimiter; Billari, Francesco C. (Eds.): Policy implications of changing family formation. Strasbourg: Council of Europe Publishing: 117-181.

Hoem, Jan; Kostova, Dora; Jasilioniene, Aiva; Mureşan, Cornelia 2009: Traces of the Second Demographic Transition in four selected countries in Central and Eastern Europe: Union formation as a demographic manifestation. In: European Journal of Population 25,3: 239-55.

lacovou, Maria 2004: Patterns of family living. In: Berthoud, Richard; lacovou, Maria (Eds.): Social Europe. Living standards and welfare states. Cheltenham: Edgar Elgar: 21-45.

lacovou, Maria 2013: The relationship between incomes and living arrangements: variation between countries, over the life course, and over time. In: ImPRovE Discussion Paper, 13/15. Antwerp [URL: http://improve-research.eu/?page_id=37].

lacovou, Maria; Skew, Alexandra J. 2010: Household structure in the EU. Methodologies and working papers. Luxembourg: Publications Office of the European Union. 
lacovou, Maria; Skew, Alexandra J. 2011: Household composition across the new Europe: Where do the new Member States fit in? In: Demographic Research 25: 465-490 [doi: 10.4054/DemRes.2011.25.14].

Kalmijn, Matthijs; Saraceno, Chiara 2008: A comparative perspective on intergenerational support. In: European Societies 10,3: 479-508 [doi: 10.1080/14616690701744364].

Kertzer, David I. 1991: Household history and sociological theory. In: Annual Review of Sociology 17: 155-179 [doi: 10.2307/2083339].

Kiernan, Kathleen 1986: Leaving home: Living arrangements of young people in six West-European countries. In: European Journal of Population 2,2: 177-184 [doi: 10.1007/BF01796889].

Kuijsten, Anton C. 1996: Changing family patterns in Europe: A case of divergence? In: European Journal of Population 12,2: 115-143 [doi: 10.1007/BF01797080].

Lesthaeghe, Ron 1995: The second demographic transition in Western countries: An interpretation. Gender and family change in industrialized countries. In: Oppenheim Mason, Karen; Jensen, An-Magritt (Eds.): Gender and family change in industrialized countries. New York: Oxford University Press: 17-62.

Lesthaeghe, Ron; Moors, Guy 1995: Living arrangements, socioeconomic position, and values among young adults: A pattern description for Belgium, France, the Netherlands and West Germany, 1990. In: van den Brekel, Hans; Deven, Fred (Eds.): Population and family in the Low Countries 1994. Dordrecht: Springer: 1-56.

Mills, Melinda; Blossfeld, Hans-Peter 2013: The Second Demographic Transition meets globalization: A comprehensive theory to understand changes in family formation in an era of rising uncertainty. In: Evans, Ann; Baxter, Janeen (Eds.): Negotiating the life course. Stability and change in life pathways. Dordrecht: Springer: 9-33.

Minnesota Population Center 2011: Integrated Public Use Microdata Series, International: Version 6.1. Machine-readable database. Minneapolis: University of Minnesota [https://international.ipums.org/international/citation.shtml].

Raftery, Adrian E. 1995: Bayesian model selection in social research. In: Sociological Methodology 25: 111-163 [doi: 10.2307/271063].

Reher, David S. 1998: Family ties in Western Europe: Persistent contrasts. In: Population and Development Review 24,2: 203-234 [doi: 10.2307/2807972].

Rindfuss, Ronald R. 1991: The young adult years: Diversity, structural change, and fertility. In: Demography 28,4: 493-512 [doi: 10.2307/2061419].

Sobek, Matthew; Kennedy, Sheela 2009: The development of family interrelationship variables for international census data. In: Minnesota Population Center Working Paper Series 2009-02 [https://www.pop.umn.edu/research/working-papers].

Sobotka, Tomáš 2008: Overview Chapter 6: The diverse faces of the Second Demographic Transition in Europe. In: Demographic Research 19: 171-224 [doi: 10.4054/ DemRes.2008.19.8].

Sobotka, Tomáš; Toulemon, Laurent 2008: Overview Chapter 4: Changing family and partnership behaviour: Common trends and persistent diversity across Europe. In: Demographic Research 19: 85-138 [doi: 10.4054/DemRes.2008.19.6].

Steinbach, Anja 2012: Intergenerational relations across the life course. In: Advances in Life Course Research 17,3: 93-99 [doi: 10.1016/j.alcr.2012.06.002].

Stone, Juliet; Berrington, Ann; Falkingham, Jane 2011: The changing determinants of UK young adults' living arrangements. In: Demographic Research 25: 629-666 [doi:10.4054/DemRes.2011.25.20]. 
Zorlu, Aslan; Mulder, Clara H. 2010: Location choices of migrant nest-leavers: Spatial assimilation or continued segregation? In: Advances in Life Course Research 15,2-3: 109-120 [doi:10.1016/j.alcr.2010.06.001].

Katrin Schwanitz ( $₫)$. University of Groningen, Faculty of Spatial Sciences, Department of Demography. Groningen, The Netherlands. E-mail: k.v.schwanitz@rug.nl

URL: http://www.rug.nl/staff/k.v.schwanitz/

Institut National d’Etudes Demographiques (Ined). Paris, France.

E-mail: katrin.schwanitz@ined.fr

URL: https://www.ined.fr/en/directory/katrin-schwanitz/512

Prof. Dr. Clara H. Mulder. University of Groningen, Faculty of Spatial Sciences, Department of Demography. Groningen, The Netherlands. E-mail: c.h.mulder@rug.nl URL: http://www.rug.nl/staff/c.h.mulder/ 


\section{Comparative Population Studies}

WWW.comparativepopulationstudies.de

ISSN: 1869-8980 (Print) - 1869-8999 (Internet)

Published by / Herausgegeben von

Prof. Dr. Norbert F. Schneider

Federal Institute for Population Research

D-65180 Wiesbaden / Germany

\section{Managing Editor /}

Verantwortlicher Redakteur

Frank Swiaczny

\section{Assistant Managing Editor /}

\section{Stellvertretende Redakteurin}

Katrin Schiefer

\section{Copy Editor (German) /}

Lektorat (deutsch)

Dr. Evelyn Grünheid

\section{Layout / Satz}

Beatriz Feiler-Fuchs

E-mail:cpos@bib.bund.de

\section{Scientific Advisory Board /}

Wissenschaftlicher Beirat

Paul Gans (Mannheim)

Johannes Huinink (Bremen)

Michaela Kreyenfeld (Rostock)

Marc Luy (Wien)

Clara H. Mulder (Groningen)

Notburga Ott (Bochum)

Peter Preisendörfer (Mainz)

Zsolt Spéder (Budapest)
Board of Reviewers / Gutachterbeirat Martin Abraham (Erlangen)

Laura Bernardi (Lausanne)

Hansjörg Bucher (Bonn)

Claudia Diehl (Konstanz)

Andreas Diekmann (Zürich)

Gabriele Doblhammer-Reiter (Rostock)

Jürgen Dorbritz (Wiesbaden)

Anette Eva Fasang (Berlin)

E.-Jürgen Flöthmann (Bielefeld)

Alexia Fürnkranz-Prskawetz (Wien)

Beat Fux (Salzburg)

Joshua Goldstein (Berkeley)

Karsten Hank (Köln)

Sonja Haug (Regensburg)

Hill Kulu (Liverpool)

Aart C. Liefbroer (Den Haag)

Kurt Lüscher (Konstanz)

Emma Lundholm (Umeå)

Nadja Milewski (Rostock)

Dimiter Philipov (Wien)

Roland Rau (Rostock)

Tomáš Sobotka (Wien)

Jeroen Spijker (Barcelona)

Olivier Thévenon (Paris)

Helga de Valk (Brussel)

Heike Trappe (Rostock)

Michael Wagner (Köln) 